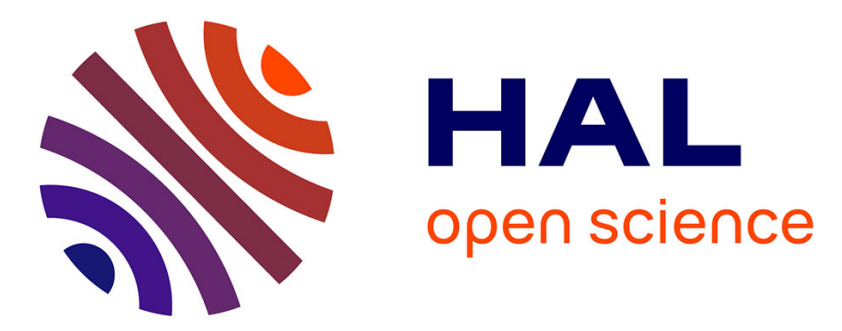

\title{
Global Value Chains in Shipbuilding: Governance and Knowledge Exchange
}

\author{
Lise Lillebrygfjeld Halse
}

\section{To cite this version:}

Lise Lillebrygfjeld Halse. Global Value Chains in Shipbuilding: Governance and Knowledge Exchange. IFIP International Conference on Advances in Production Management Systems (APMS), Sep 2014, Ajaccio, France. pp.209-216, 10.1007/978-3-662-44739-0_26 . hal-01388246

\section{HAL Id: hal-01388246 \\ https://inria.hal.science/hal-01388246}

Submitted on 26 Oct 2016

HAL is a multi-disciplinary open access archive for the deposit and dissemination of scientific research documents, whether they are published or not. The documents may come from teaching and research institutions in France or abroad, or from public or private research centers.
L'archive ouverte pluridisciplinaire HAL, est destinée au dépôt et à la diffusion de documents scientifiques de niveau recherche, publiés ou non, émanant des établissements d'enseignement et de recherche français ou étrangers, des laboratoires publics ou privés.

\section{(c)(1)}

Distributed under a Creative Commons Attribution| 4.0 International License 


\title{
Global Value Chains in Shipbuilding: Governance and knowledge exchange
}

\author{
Lise Lillebrygfjeld Halse \\ Molde University College, Specialized University in Logistics \\ lise.l.halseahimolde.no
}

\begin{abstract}
Over the last decades, the Norwegian shipbuilding industry has become increasingly globalized, with offshoring of production of to low cost locations. Globally dispersed production of complex and customized ships has proven to be challenging with respect to coordination of activities and exchange of knowledge. The paper investigates how different governance alternatives affect knowledge exchange in the global value chains of two shipbuilding groups. The findings indicate that vertical integration facilitates coordination and knowledge transfer to foreign shipyards. However, reverse knowledge transfer through these linkages seems to be limited. This may have implications for the future innovativeness of this industry.
\end{abstract}

Keywords: Global Value Chains, Supply Chain Management, Knowledge, Shipbuilding

\section{Introduction}

The latest decades have been characterized by an increasing globalization, which has led to geographically dispersed production networks, pushed forward by intensified competition and cost focus. This development challenges companies in high-cost countries. Reducing production costs by introduction of automation, often combined with systems for production efficiency such as Lean, is one way of meeting this challenge. Another is to focus more on product differentiation and innovativeness [1]. The latter strategy has been pursued by the Norwegian Maritime cluster, which delivers complex and customized vessels for offshore purposes, and categorized as Engineer-To-Order (ETO) producers [2]. Furthermore, the innovative strength of this industry has been ascribed to close user-producer linkages between geographically proximate actors, where knowledge has been easily transferred [3]. Despite being leading in this market segment, price competition has led to increased offshoring of production to low-cost locations. Due to more geographically disperse value chains this development may represent a challenge for the innovativeness of this industry. On the other hand, global production networks can be considered as knowledge networks, where companies can access knowledge from foreign knowledge sources, which they can combine with their own internal knowledge base. A widespread view in the literature is that the most innovative firms access international sources of knowledge, where they merge a strong

adfa, p. 1, 2011.

(C) Springer-Verlag Berlin Heidelberg 2011 
local knowledge base with high levels of connectivity to other regions in the global network $[4,5]$. However, the type and amount of knowledge that is exchanged will depend on the form of cooperation established between the companies in the supply network. Little attention has been drawn to how the coordination of global supply networks will affect the knowledge sharing in those networks [6]. Furthermore, literature on management or coordination of global supply chains of ETO industry is scarce [2]

This paper aims at filling this gap in the literature by providing two case studies of two shipbuilding companies residing in the Norwegian maritime cluster. First, I apply the concept of governance to investigate the forms of coordination implemented by the two shipbuilding groups in their global linkages, associated with their core activities: design and production of ships. I then investigate how the choice of governance affects knowledge sharing in these linkages. The remainder of this paper is structured as follows: First, the theoretical framework applied in this study is presented. Thereafter, a brief description of the Norwegian shipbuilding industry and the research methodology is provided. Then the main shipbuilding processes are presented, shedding light on governance and knowledge flow in global linkages. Finally, the findings are discussed ending in conclusions and suggestions for further research.

\section{Theoretical background}

The literature presented in this paper draws on a typology for governance of global value chains rooted in transaction cost economics, production networks theory and the concept of technological capability. This framework is then extended to capture what implications the choice of governance will have for knowledge sharing in global value chains.

\subsection{Governance of Global Value Chains (GVC)}

Transaction cost theory has provided an important theoretical base for conceptualizing the form of coordination within supply chains. The governance concept provides a theoretical explanation of the most efficient way of organizing transactions between companies [7]. Authors provide different typologies of governance, ranging from arm's length market dynamics at one end of the scale, to hierarchical structures on the other. Gereffi et al. [8] offer a typology that helps explaining governance patterns in global value chains. They identify three variables that play a large role in determining how global value chains are governed: the complexity of transactions, the codifiability of knowledge, and the capabilities in the supplier base. Based on different combinations of these, they separate between five ideal governance types, where the governance types represent different degrees of explicit coordination and power asymmetry: market, modular, relational, captive and hierarchical. In the market type of governance, product specifications are simple, knowledge exchange is mainly price information, and the number of possible suppliers is large. In modular value chains, the product complexity is greater, but it is possible to codify the information with the use of standards, which makes it possible to easily switch supplier. The relational form of governance is based 
on mutual dependence, loyalty and trust, which has its basis in a common culture, developed through shared history and experience of the agents. The relational form of governance emerges when the information associated with products is complex, when the transferred knowledge is typically tacit and requires face-to-face contact between actors, and when supplier capabilities are high. In captive value chains, the supplier is dependent on the much larger buyers, and relations are characterized by high degree of control by lead firm. This mode of governance will emerge when products are complex, when it is difficult to codify information and when supplier capabilities are low [8]. The hierarchal type of governance corresponds to vertical integration of suppliers, which is appropriate when products are complex and when the codifiability and the capabilities in the supplier base are low. As Gereffi et al. (2005) point out different industries may change between the different forms of governance in a dynamic manner.

\subsection{Governance and knowledge}

Pietrobelli and Rabelotti [9] find that learning mechanisms can vary widely within the various forms of governance of global value chains (GVC), using the governance typology of Gereffi et al. [8]. Similarly, Isaksen and Kalsaas [1] analyze possibilities for knowledge upgrading and innovation activities in global production networks and argue that firms' possibilities for learning and knowledge upgrading depend on how the network is governed. Based on these theoretical frameworks, table 1 presents the forms of knowledge exchange and innovation opportunities associated with the different forms of governance in Gereffi et al.'s typology.

Fig. 1. Table 1. Governance and knowledge flow in global value chains

\begin{tabular}{|c|c|c|}
\hline Governance & $\begin{array}{l}\text { Form of infor- } \\
\text { mation/ } \\
\text { knowledge }\end{array}$ & $\begin{array}{l}\text { Knowledge exchange and innovation in supply } \\
\text { chain }\end{array}$ \\
\hline Market & $\begin{array}{l}\text { Price, simple } \\
\text { product specifica- } \\
\text { tion }\end{array}$ & $\begin{array}{l}\text { No deliberate knowledge transfer between compa- } \\
\text { nies, innovation through knowledge spillovers and } \\
\text { imitation (competitors) }\end{array}$ \\
\hline Modular & $\begin{array}{l}\text { Standards, ex- } \\
\text { plicit knowledge }\end{array}$ & $\begin{array}{l}\text { Knowledge transfer through standards, codes and } \\
\text { technical definitions. Innovations related to develop- } \\
\text { ment and improvements of standards and production } \\
\text { processes. }\end{array}$ \\
\hline Relational & $\begin{array}{l}\text { Explicit and tacit } \\
\text { knowledge }\end{array}$ & $\begin{array}{l}\text { Intense knowledge transfer through face-to-face in- } \\
\text { teraction, innovation of product through close inter- } \\
\text { action between companies in network having com- } \\
\text { plementary competence. }\end{array}$ \\
\hline Captive & Explicit and tacit & $\begin{array}{l}\text { Deliberate knowledge transfer from lead firm typi- } \\
\text { cally related to narrow range of tasks, typically re- } \\
\text { lated to production. }\end{array}$ \\
\hline Hierarchy & Explicit and tacit & $\begin{array}{l}\text { Deliberate knowledge transfer, arenas for knowledge } \\
\text { exchange, training programs. Cooperative innovation } \\
\text { depends on power relations and competence. }\end{array}$ \\
\hline
\end{tabular}




\section{The Norwegian shipbuilding industry}

The Norwegian shipbuilding industry fosters innovations in the design, engineering and construction of offshore and specialized vessels to the offshore sector, creating a global niche through a focus on product innovation and management of complex projects. The vessels produced by this industry are built on a high degree of customization for individual customers. Despite of high cost associated with this strategy, the industry has proved to be successful, most probably due to high degree of innovativeness and being world leading in systems integration. One of the most important characteristic of Norwegian shipbuilding industry is its flexibility, which gives customers the possibility to decide many features of the vessel quite late during the shipbuilding process [10].

The actors in this industry can be divided into four major groups [11]: shipping companies (ship owner), design companies, shipyards, and equipment suppliers. The present study focuses on two shipbuilding groups. Both of these groups, however, have their own design companies delivering design to own and other shipyards.

\section{$4 \quad$ Research method}

In order to investigate the link between governance and knowledge transfer in global value chains in an ETO setting, I chose an explorative multiple case study [12]. The two largest shipbuilding groups in the Norwegian maritime cluster in North West Norway were chosen as cases in this study. The main data collection was performed through in-depth, semi-structured interviews of key personnel and through observations in meetings in central cluster companies, subsidiaries, suppliers, and representatives in foreign locations in China, the Netherlands, Poland and Brazil.

Shipbuilding group 1 has a global owner and consists of four separate shipyards in the cluster, and four at foreign locations. During the last years the group has built up a design company delivering design to own shipyards. Shipbuilding group 2 is family owned, and has one shipyard in the cluster. The group has long experience in designing vessels for its own shipyard and for foreign shipyards. Expanding the design and project management activity of the company has been the primary strategy the last years, as the production capacity of their shipyard is limited.

\section{$5 \quad$ The shipbuilding process}

Figure 1 identifies the main stages in the shipbuilding process ${ }^{1}$ discussed in this paper. The conceptual and basic design process takes place within the cluster. However, the subsequent stages in the supply chain differ with respect to localization, depending on

1 This figure represents a simplified and sequential image of the shipbuilding process. In reality, engineering, procurement, and production activities are performed in near concurrency throughout the project execution (concurrent shipbuilding). 
the type of project undertaken, and the customer's needs. Two different production processes can be identified, representing value chains with different degrees of outsourcing to low-cost locations (offshoring). In the first process, A, basic design is performed within the cluster, and detailed design is performed in the cluster and at foreign engineering companies. Production of hulls is outsourced to low cost country locations, while most part of the outfitting, testing and delivery is undertaken locally in the cluster. Parts of outfitting are in some cases performed at foreign shipyards, and the strategy is to increase this activity abroad. In the second process (B) only conceptual design, basic design and parts of detailed engineering is carried out locally in the cluster. Parts of detailed engineering and the complete fabrication of the vessel are carried out at foreign locations in low-cost countries. The focus of this study is the part of the processes that is associated with the transition between engineering and production, including outfitting.

In the following, governance and knowledge transfer in the linkages between the Norwegian shipbuilding groups and the foreign company in each of these processes is discussed separately.

Fig. 2. Shipbuilding processes in the Norwegian maritime cluster

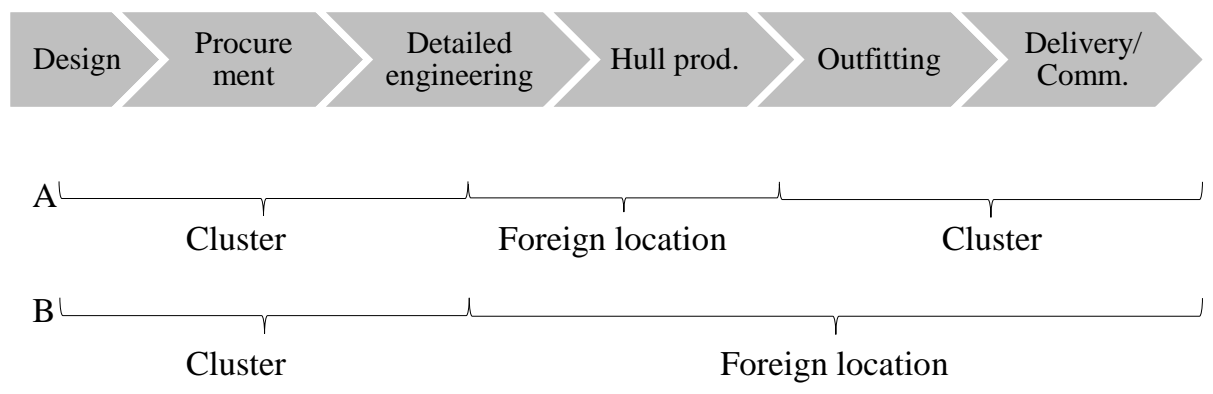

\subsection{Process A}

After the conceptual design phase, the contract is signed with a shipyard. A basic phase then follows where more detailed drawings of the vessel are made, before the ideas in the conceptual and basic design is translated into detailed engineering. The production of the hull is then started at a foreign yard. In this process, the main global linkage is between a Norwegian shipyard and the foreign hull yard. In principle, the production of hulls is not very complex, and the knowledge and information that needs to be transferred is mainly of explicit nature. Consequently, and according to Gereffi et al. [8], several modes of governance could be appropriate in the link towards the hull yards.

Shipbuilding group 1 has chosen to acquire foreign companies in low cost countries in order to perform the work intensive parts of the shipbuilding process, as construction of hulls. Since the 1990s, they have owned several foreign hull yards. Respondents in this company argue that this strategy allows for control over the supply chain with regard to capacity, work processes and knowledge flow. However, the first years after the acquisition, there were challenges regarding the quality of the hulls (e.g. welding). 
These problems have been reduced over the years. Today there is considerable information and knowledge exchange between the home yards and the foreign hull yards, in particular related to production planning. Knowledge and information is frequently exchanged between the regional shipyards and the foreign hull yards. To further reduce costs the shipyard is in a process of moving activities like simple equipping from the local shipyards to the hull yards. However, this process has proven to be challenging, due to quality issues and delivery time.

Shipbuilding group 2 has chosen not to own the foreign hull yards, but has sought to establish cooperation with some foreign shipyards. The reason for this strategy is mainly based on financial risk and market considerations. However, Shipbuilding group 2 has not been able to establish long-term relationship with a particular foreign hull yard. According to theory, this may hamper knowledge and information exchange between the companies.

\subsection{Process B}

In this process, the global linkages must handle more complex interactions, as the complete vessel is being built at a foreign location. The global linkages in this process is typically between a Norwegian design/engineering company and a foreign shipyard.

Both shipbuilding groups deliver complex and customized vessels and can be categorized as Engineer-To-Order (ETO) producers [2]. Traditionally, there has been exchange of dominantly tacit knowledge through face-to-face interaction between regional actors in the shipbuilding process, which is well adapted to this kind of production. From Table 1, we see that the relational form of governance corresponds to this form of knowledge exchange, which also has been the prominent form of governance regionally in the maritime cluster. This form of governance is, however, difficult to sustain over longer geographical distances. Consequently, the shipbuilding groups have to find other forms of governance towards foreign shipyards.

Shipbuilding group 1 owns wholly or partially the foreign shipyards (vertical integration). They have employees from their home yards stationed at foreign yards, which according to the respondents is critical in order to achieve project success. These persons have important roles in the knowledge transfer between the Norwegian design/engineering environment and the foreign shipyard. Vertical integration is in line with Gereffi et al. [8], as the production of complete offshore supply vessels is complex, the information to be transferred is difficult to codify, and the foreign shipyards are reported to have low competence in building such vessels.

Shipbuilding group 2 exerts looser ties to the foreign shipyards. Their strategy in this process is to take a supplier role, delivering design, equipment packages and project management. By using standards and specifications, they aim at making the interface between the design company and the foreign shipyard more 'clean', allowing for more flexibility in the selection of foreign shipyards, in accordance with the modular form of governance [8]. This implies transfer of knowledge associated with the shipbuilding process from tacit to explicit. Moreover, this approach requires codifiability of information related to building and equipping the vessel, which implies a development to- 
wards making standardized or simpler vessels compared to the advanced and customized vessels the cluster companies are renowned for. Furthermore, the complex and flexible nature of the ETO shipbuilding process represents an opportunity for selling project management competence to foreign shipyards. However, the mismatch between the competence and responsibility balance in the relationship with the foreign shipyards represents a challenge: With respect to competence, Shipbuilding group 1 is in power relative to the foreign shipyard, which resembles the captive form of governance in figure 1. The Shipbuilding group has, however, no formal responsibility in its relationship with the shipyards, as it only is a supplier of design and project management to the foreign shipyards. This mismatch may hamper knowledge exchange in the relationship.

Both shipbuilding groups report, independent of form of governance, that cultural barriers, and a different way of producing vessels at the foreign shipyards, represent challenges in carrying out shipbuilding projects at foreign shipyards. Cultural issues are in particular related to hierarchy and power distance [13]. The complex nature of the production process of these vessels represents a challenge in a hierarchical production environment where workers are used to receiving orders and detailed instructions. Consequently, the design and engineering departments have found it necessary to increase the level of detail in project plans and technical drawings.

\section{Discussion and implications}

In this paper the choice of governance in global value chains of two shipbuilding groups has been studied. The paper identifies two dominant production processes with varying degree of offshoring of production. In the first (A), most of the complex work is still kept inside the cluster, which makes it possible to continue the traditional relational form of governance in large parts of the supply chain. In the second process (B), only design, some engineering and project management is kept within the cluster, while the production is carried out at foreign shipyards. This represents considerable challenges for coordination of activates along the value chain. The findings in this study largely confirms the theoretical framework provided by Gereffi et al. [8], which predicts that hierarchical governance is appropriate when complexity is high, supplier capability is low and codifiability is low. Regarding knowledge, the findings indicate that vertical integration may provide stable relationship and gradually building of knowledge at the foreign production facilities, whereas building a global value chain is challenging for a shipbuilding group taking the role as a supplier of design of such complex and customized vessels.

Independent of governance alternatives, findings indicate that the shipbuilding groups to a small extent acquire and take advantage of knowledge from the foreign production sites. This reflects that the innovation processes primarily takes place in the conceptual design phase, which still is regional, involving local demanding customers, design companies, shipyards and suppliers of advanced equipment [14]. The process is characterized by face-to-face contact and exchange of tacit knowledge. Personnel involved in this process often has a background from the construction of vessels, indicating that this knowledge is important also for the design process. From this perspective, 
increased global sourcing of production may hamper future innovativeness of this industry. This issue should be subject for further research.

\section{$7 \quad$ References}

1. Isaksen, A., Kalsaas, B.: Suppliers and Strategies for Upgrading in Global Production Networks: The Case of a Supplier to the Global Automotive Industry in a High-cost Location. European Planning Studies. 17(4), 569-585 (2009)

2. Haartveit, D.G.,Semini, M., Alfnes, E.: Integration Alternatives for Ship Designers and Shipyards, In, Frick, J., Laugen, B., (eds.) Advances in Production Management Systems. Value Networks: Innovation, Technologies, and Management. pp. 309-316. Springer Berlin Heidelberg (2012)

3. Asheim, B., T., Isaksen, A.: Regional Innovation Systems: The Integration of Local 'Sticky' and Global 'Ubiquitous' Knowledge. Journal of Technology Transfer. 27(1), 77-86 (2002)

4. Semlinger, K.: Cooperation and competition in network governance: regional networks in a globalised economy. Entrepreneurship and Regional Development. 20(6), 547-560 (2008)

5. MacKinnon, D.: Beyond strategic coupling: reassessing the firm-region nexus in global production networks. Journal of Economic Geography. 12(1), 227 (2012)

6. Iammarino, S., McCann, P.: The structure and evolution of industrial clusters: Transactions, technology and knowledge spillovers. Research policy. 35(7), 1018-1036 (2006)

7. Williamson, O.E.: Transaction-cost economics: the governance of contractual relations. Journal of Law and Economics. 22(2), 233-261 (1979)

8. Gereffi, G.,Humphrey, J., Sturgeon, T.: The governance of global value chains. Review of International Political Economy. 12(1), 78-104 (2005)

9. Pietrobelli, C., Rabellotti, R.: Global Value Chains Meet Innovation Systems: Are There Learning Opportunities for Developing Countries? World Development. 39(7), 1261-1269 (2011)

10. Semini, M., et al.: Strategies for customized shipbuilding with different customer order decoupling points. Proceedings of the Institution of Mechanical Engineers, Part M: Journal of Engineering for the Maritime Environment, (2014)

11. Hervik, A., et al.: NCE Maritime klyngeanalyse 2012 : status for maritime næringer i Møre og Romsdal. Møreforsking Molde AS. Molde (2012)

12. Yin, R.K.: Case study research: design and methods. Sage. Los Angeles (2009)

13. Hofstede, G.,Hofstede, G.J., Minkov, M.: Cultures and organizations: software of the mind : intercultural cooperation and its importance for survival. McGraw-Hill. New York (2010)

14. Hammervoll, T.,Engelseth, P., Halse, L.L.: The Role of Clusters in Global Maritime Value Networks. International Journal of Physical Distribution \& Logistics Management. 44(2) (2014) 